\title{
Short-term intravenous zoledronic acid in severe osteogenesis imperfecta : A report of three siblings of children
}

\author{
Hadyanto Lim, ${ }^{1}$ Umar Zein, ${ }^{2}$ Yahwardiah Siregar, ${ }^{3}$ Blondina Marpaung, ${ }^{4}$ Jaminsen Sinaga ${ }^{5}$
}

\begin{abstract}
Abstrak
Laporan ini memuat efek samping klinis dan biokimia pemberian zoledronic acid dosis awal pada tiga anak bersaudara dengan osteogenesis imperfecta berat. Zoledronic acid diberikan dalam $50 \mathrm{ml}$ larutan garam fisiologis selama 30 menit. Semua pasien mengalami demam dalam kurun waktu 6-48 jam setelah pemberian infus pertama. Tidak ada efek samping terhadap fungsi ginjal, kecuali hipokalsemia dan hipofosfatemia, yang terjadi dalam 48 jam dan 72 jam setelah infus zoledronic acid. Efek samping minimal dapat diatasi dengan mudah. (Med J Indones 2008; 17: 127-30)
\end{abstract}

\begin{abstract}
This report documented the clinical and biochemical side effects on the first dose of intravenous zoledronic acid therapy in three siblings with severe osteogenesis imperfecta. Zoledronic acid was administered in $50 \mathrm{ml} 0.9 \%$ saline solution over a period of 30 minutes. All patients had fever during the first 6 to 48 hours after the first infusion. There were no renal side effects, apart from asymptomatic hypocalcemia and hypophosphatemia at 48 and 72 hours after zoledronic acid infusion. The minimal clinical side effects were easily manageable. (Med J Indones 2008; 17: 127-30)
\end{abstract}

Keywords: zoledronic acid, osteogenesis imperfecta, side effects

Zoledronic acid is a very potent, nitrogen-containing biphosphonate for intravenous administration ${ }^{1}$ and currently has been approved by the United States Food and Drug Administration (FDA) for use for various skeletal indications. ${ }^{2}$ According to in vitro and animal studies, it has the potency of up to 100 to 850 times than that of pamidronate for osteoclast inhibition. ${ }^{3}$ It has the advantage that it can be administered over 30 minutes as a single infusion every three months, thus reducing the need for hospital admission. ${ }^{3}$

1 Department of Pharmacology, Faculty of Medicine, Methodist University of Indonesia/ Methodist Susanna Wesley Hospital, Medan, Indonesia

2 Division of Tropical Medicine and Infectious Diseases, Department of Internal Medicine, Faculty of Medicine, University of Sumatra Utara, Medan, Indonesia

3 Department of Biochemistry, Faculty of Medicine, University of Sumatra Utara, Medan, Indonesia

4 Division of Rheumatology, Department of Internal Medicine, Adam Malik General Hospital-Medan, Indonesia

5 Department of Pediatrics, Faculty of Medicine, Methodist University of Indonesia/ Methodist Susanna Wesley Hospital, Medan, Indonesia
In adults, zoledronic acid had been successfully used for the treatment of malignancy-induced hypercalcemia (HCM $),{ }^{4}$ and metastatic bone disease. ${ }^{5}$ However, a recent survey has raised concerns about altered renal function after zoledronic acid in adults with metastatic bone cancer. $^{6}$ The binding of zoledronic acid to bone surface leads to inhibit the physiologic release of calcium and phosphorus from bone tissue into the circulating pool. ${ }^{1}$

The acute side effects of pamidronate, such as fever, myalgia, nausea and vomiting are known to occur during the first infusion in children with osteogenesis imperfecta. ${ }^{7}$ We report our experience on the clinical and biochemical side effects on the first dose of intravenous zoledronic acid therapy in three siblings with severe osteogenesis imperfecta. To our knowledge, this is the first report regarding the use of zoledronic acid to three siblings with severe osteogenesis imperfecta. ${ }^{14}$

\section{CASE REPORT}

In November 2006, three siblings of children, 2 to 6 years old, who had severe osteogenesis imperfecta, received intravenous zoledronic acid in our hospital. 
All had severe osteopenia and fracture (Figure 1) (Table 2 ), and severe restriction in ambulation.

All subjects received zoledronic intravenous infusion $(0.015 \mathrm{mg} / \mathrm{kg})$, administered in $50 \mathrm{ml} 0.9 \%$ saline solution over a period of 30 minutes. The dose was based on children experience treating osteoporosis. ${ }^{1}$ The dose was amended to use $0.015 \mathrm{mg} / \mathrm{kg}$ (Table 1), and would be followed by $0.025 \mathrm{mg} / \mathrm{kg} 12$ weeks after the first dose. The presence of fever (temp $>38^{\circ} \mathrm{C}$ ), myalgia, nausea and/or vomiting, muscle cramps, twitching were recorded for the first 72 hours after infusion. Serum levels of total calcium and inorganic phosphorus at baseline and 48 and 72 hours after infusion as well as creatinine and urea were analyzed by using routine laboratory methodology. Baseline serum alkaline phosphatase, a marker of bone formation, ${ }^{7}$ was measured by calorimetric method. The urinary excretion of the cross-linked $\mathrm{N}$ telopeptide/creatinine of the type I collagen ( $\mathrm{uNTX} / \mathrm{uCr}$ ), a marker of bone resorption, ${ }^{8}$ was measured by enzyme-linked immunosorbent assay (Valencia, CA, USA).

X-ray films of the spine (anteroposterior and lateral views) were obtained before administration of zoledronic acid and would be obtained at 6-12 months interval. (Figure 1).

All patients were supplemented with 2 gram of calcium and $532 \mathrm{mg}$ vitamin D in four tablets of Calvit D3 per day, for 10 days before infusion. Acetaminophen was chosen for the possible adverse effects.

\section{Biochemical Changes}

Before treatment, all 3 children had normal serum calcium, inorganic phosphorus, creatinine and urea levels. Changes of serum calcium and phosphorus, creatinine and urea at 48 and 72 hours after zoledronic acid infusion (Table 3).

Table 1. Characteristics of three siblings with osteogenesis imperfecta before zoledronic infusion

\begin{tabular}{lcccccc}
\hline Patients & $\begin{array}{c}\text { No } \\
(\mathrm{y}, \mathrm{m})\end{array}$ & $\begin{array}{c}\text { Age } \\
(\mathrm{cm})\end{array}$ & $\begin{array}{c}\text { Height } \\
(\mathrm{cm})\end{array}$ & $\begin{array}{c}\text { Serum Alkaline } \\
\text { Phosphatase } \\
(\text { Unit/liter })(\text { Ref. R)* }\end{array}$ & $\begin{array}{c}\text { Urinary Type I Collagen } \\
\text { N-Telopeptidase/creatinine } \\
(\mathrm{nM} \text { BCE/mM) (Ref..R) }\end{array}$ & $\begin{array}{c}\text { Zoledronic Acid } \\
\text { Treatment } \\
(\mathrm{mg} / \mathrm{kg})\end{array}$ \\
\hline Boy & 1 & 5.7 & 80 & $552(115-391)$ & $2890(13-78)$ & 0.015 \\
Boy & 2 & 3.9 & 70 & $514(115-391)$ & $4221(13-78)$ & 0.015 \\
Girl & 3 & 1.10 & 70 & $417(115-460)$ & $2387(14-74)$ & 0.015 \\
\hline
\end{tabular}

* Ref. $\mathrm{R}$ indicates reference range as established in the accredited laboratory

\# Ref. R indicates reference range as established in the specialty laboratory (Valencia, CA, USA)

Table 2. Radiological findings of patients with osteogenesis imperfecta

\begin{tabular}{lccc}
\hline Patient & Spine Abnormalities & Osteopenia & Deformity \\
\hline Boy & Biconcave vertebra & Yes & Bowing extremities, Bulbous distal \\
Boy & Biconcave vertebra & Yes & Bowing extremities, fractures \\
Girl & Biconcave vertebra & Yes & Bowing extremities, fractures \\
\hline
\end{tabular}

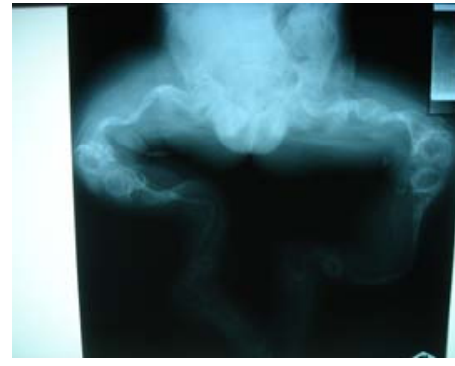

(A)

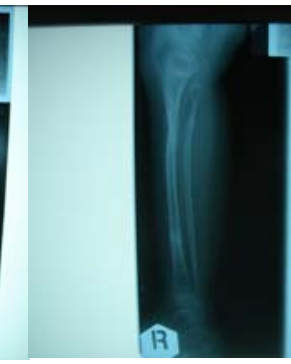

(B)

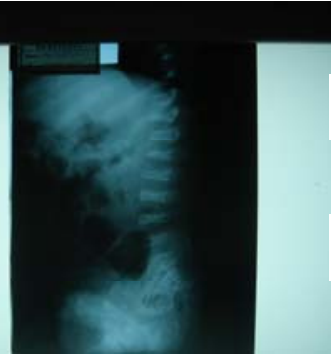

(C)

Figure 1. (A) Bulbous distal metaphyses (patient 1). (B) Lower extremity showing fracture, and bowing (patient 2). (C) Lumbal spine showing biconcave configuration and multiple lytic lesions (patient 3). 
Table 3. Changes in total calcium and phosphorus profile (in $\mathrm{mg} / \mathrm{dl}$ ), and renal function at baseline and 48 and 72 hours after zoledronic acid infusion

\begin{tabular}{lcccc}
\hline Levels & Calcium & Phosphorus & Creatinine & Urea \\
\hline Preinfusion & $9.80 \pm 0.10$ & $5.00 \pm 0.60$ & $0.17 \pm 0.04$ & $6.67 \pm 0.58$ \\
At 48 hours & $8.76 \pm 0.46$ & $2.67 \pm 0.61$ & $0.17 \pm 0.03$ & $7.33 \pm 1.53$ \\
At 72 hours & $9.06 \pm 0.06$ & $2.63 \pm 0.50$ & $0.13 \pm 0.04$ & $7.67 \pm 0.58$ \\
\hline
\end{tabular}

Values are means \pm SD obtained from three siblings.

Reference data ${ }^{1}$ : calcium total : children 8.4-10.4 mg/dl; phosphate : children 3.0-6.0 mg/dl.

\section{Clinical Outcome and Side Effects}

All patients had fever during the first 6 to 48 hours after the first infusion. The eldest child had fever 6 hours after infusion, and nausea. The second child had fever 24 hours after infusion, earlier than the third child who had fever 40 hours later. All side effects could be managed with standard doses of acetaminophen.

\section{DISCUSSION}

Severe osteogenesis imperfecta (OI) is a heritable disorder characterized by osteopenia, frequent fractures, progressive deformity, loss of mobility, and chronic bone pain. ${ }^{7}$ In this report of three siblings of children with severe osteogenesis imperfecta (OI), zoledronic acid administration led to a marked reduction in calcium and inorganic phosphorus levels (Table 3), probably reflecting the diminished calcium influx from bone into the circulating pool. The relative magnitude of these changes was similar to that reported for children who received biphosphonates, ${ }^{1,7,9,10,11,12}$ and in adults who received iv pamidronate for Paget's disease. ${ }^{13}$

Hypocalcemia and hypophosphatemia were not associated with clinical manifestations in our patients, which are known side effects of intravenous biphosphonate therapy. ${ }^{1,9}$ It should be noted that a high calcium intake was maintained before and during the infusion cycle. Our data suggest that sufficient calcium intake and close clinical supervision are especially important during the first infusion cycle. The rationale of adding calcium arises from the recognition that the body depends on a gastrointestinal source of extracellular calcium, particularly after its supply from bone resorption was attenuated by zoledronic acid infusion. ${ }^{1}$ The marked decline in serum phosphorus concentrations probably reflects the combined result of decreased phosphate release from bone and the phosphaturic effect of parathyroid hormone (PTH). ${ }^{9}$
The short term zoledronic acid therapy was safe and there were no renal side effects, which is encouraging given decreased creatinine excretion, a marker of muscle mass reported in severe $\mathrm{OI},{ }^{15}$ and its renal toxicity in adults with metastatic bone disease. ${ }^{1,16}$ The minimal clinical side effects were easily manageable. However, the doses used in this report was lower than that reported by Hogler et al. ${ }^{1}$

In conclusions, initial dose of zoledronic acid therapy in children with OI induces a marked decreased in calcium and inorganic phosphorus. However, this does not cause clinical problems when calcium intake is sufficient, and the acute clinical side effects were easily manageable.

\section{Acknowledgement}

The authors would like to thank the Yayasan Lestari Indo Makmur (Marga LIM) in Medan for funding the hospitalization of the three siblings of children at the Methodist Susanna Wesley Hospital, Medan.

\section{REFERENCES}

1. Hogler W, Yap F, Little D, Ambler G, McQuade M, Cowell GT. Short-term assessment in the use on intravenous zoledronic acid in children. J. Pediatr 2004; 145: 701-4.

2. Morris CD, Einhorn TA. Biphosphonate in orthopaedics surgery. J Bone Joint Surg. 2005; 87: 1609-18.

3. Shaw NJ, Bishop NJ. Biphosphonate treatment of bone disease. Arch Dis. Child 2005; 90: 494-9.

4. Wellington K, Goa KL. Zoledronic acid : a review of its use in the management of bone metastases and hypercalcemia of malignancy. Drugs 2003; 6: 417-37.

5. Rosen LS, Gordon D, Kaminski M, Howell Q, Belch A, Mackey J, et al. Long-term efficacy and safety of zoledronic acid compared with pamidronate disodium in the treatment of skeletal complications in patients with advanced multiple myeloma or breast carcinoma. Cancer 2003; 98: 1735-44.

6. Chang JT, Green L, Beitz J. Renal failure with the use of zoledronic acid. N Eng J Med 2003; 349: 1676-9. 
7. Glorieux FH, Bishop NJ, Plotkin H, Chabot G, Lanoue G, Travers R. Cyclic administration of pamidronate in children with severe osteogenesis imperfecta. N Eng J Med. 1998; 339: 947-52.

8. Brenner RE, Vetter U, Bollen AM, Morike M, Eyre DR. Bone resorption assessed by immunoassay of urinary cross-linked collagen peptides in patients with osteogenesis imperfecta. J Bone Miner Res 1994; 9:993-7.

9. Rauch F, Plotkin H, Travers R, Zeitlin L, Glorieux FH. Osteogenesis imperfecta types I, III, and IV: effect of pamidronate therapy on bone and mineral metabolism. J Clin Endocrinol Metab 2003; 88:98-9.

10. Rauch F, Travers R, Plotkin H, Glorieux FH. The effects of intravenous pamidronate on the bone tissue of children and adolescents with osteogenesis imperfecta. J Clin Invest. 2002; 110: 1293-9.

11. Batch JA, Couper JJ, Rodda C, Cowell CT, Zacharin M. Use of biphosphonate therapy for osteoporosis in childhood and adolescence. J Paediatr Child Health 2003; 39: 88-92.
12. Lteif AN, Zimmerman D. Biphosphonates for treatment of childhood hypercalcemia. Pediatrics 1998; 102: 990-3.

13. Gutteridge DH, Retallack RW, Ward LC, Stuckey BG, Stewart GO, Prince RL, Kent GN, Bhagat CI, Price RI, Thompson RI, Nicholson GC. Clinical, biochemical, hematologic, and radiographic responses in Paget's disease following intravenous pamidronate disodium: a 2-year study. Bone 1996;19:387-94.

14. Glorieux FH, Ward LM, Rauch F, Lalic L, Roughley PJ, Travers R. Osteogenesis imperfecta type VI : A form of brittle bone disease with a mineralization defect. J Bone Miner Res. 2002; 17: 30-8.

15. Heymsfield SB, Arteaga C, McManus C, Smith J, Moffitt $\mathrm{S}$. Measurement of muscle mass in humans: validity of the 24-hour urinary creatinine method. Am J Clin Nutr 1983; 37:478-94.

16. Markowitz GS, Appel GB, Fine PL, Stack JI, Kunis CL, Radhakrishnan J, Palecki W, et al. Toxic acute tubular necrosis following treatment with zoledronic acid (Zometa). Kidney Int 2003; 64:281-9. 